\title{
God or Space and Nature? Henry More's Panentheism of Space and Panpsychism of Life and Nature
}

\author{
Christian Hengstermann
}
1. Introduction: »Strato's Ghost has begun to walk of late«- Cambridge Platonist Panentheism and Panpsychism

Cambridge Platonism used to be dismissed as a somewhat anachronistic and inevitably forlorn attempt at a humanist defence of a timeless ancient theology in the era of early modern science and empiricism. However, modern research has increasingly revealed the chief representatives of the »school of Cambridge $\ll^{1}$ or the »Cambridge Enlightenment ${ }^{2}$, notably Ralph Cudworth, Henry More, John Smith and George Rust, to be pioneering thinkers and precursors of key modern notions in theoretical and practical philosophy alike. ${ }^{3}$ Their internalist epistemology constituted a powerfully-argued counterpoise to the nascent British empiricism of the likes of Thomas Hobbes and John Locke, emphasizing as it did the spontaneity and activity of the subject. Modelled upon Cartesian foundationalism, it views all truth claims as grounded in a first fundamental intuitive insight into divine goodness of which a subject possesses an a priori idea exempt from any doubt whatsoever. Likewise, in anthropology, the Cambridge Platonists propounded seminal theories of consciousness in the Cartesian vein which, for all their debt to Descartes' cogito, parted ways with the French rationalist in emphasizing accountable practical agency, rather than theoretical reasoning as the chief mode of

1 Cassirer 2002: 223-380, is the most influential proponent of the view of the Cambridge Platonists as backward-looking humanists. See also the rather negative assessment of Cambridge Platonism in Hall 1990: 40-81. On the Cambridge Platonists' use of the ancient theology for the purpose of systematic philosophical enquiry, see Hedley 2017: 932-953. This special issue of the British Journal for the History of Philosophy provides a helpful survey of contemporary Cambridge Platonist scholarship. See the exposition of their Christian Platonism in my »Pre-existence and Universal Salvation-The Origenian Renaissance in Early Modern Cambridge« (Hengstermann 2017: 971-989), as well as the general overview of their thought in my »The Cambridge Platonists« (Hengstermann in print a)

2 This is the most recent group sobriquet suggested by Hutton 2015: 136-159.

3 Cf. Lovejoy 1908: 265-302. However, the claim that they anticipated the whole of Kant's transcendental idealism is certainly exaggerated. 
human subjectivity. ${ }^{4}$ In ethics, they espoused a theory of normativity which viewed autonomous human reason as the sole source of moral obligation, ${ }^{5}$ thereby contributing decisively to the »invention of autonomy« culminating in Immanuel Kant. ${ }^{6}$ Cudworth's theory in particular has been hailed as anticipating Kantian ethical internalism in crucial regards. ${ }^{7}$ It is on the basis of their view of an »internal ought « inscribed into the human mind that they subjected contractualism, as put forward in classics of early modern political philosophy such as Thomas Hobbes' Leviathan and Baruch de Spinoza's Theological-Political Treatise, to in-depth criticism. Both their theoretical and their practical philosophy constitute what Cudworth, with one of numerous neologisms and technical concepts coined by himself, called the »philosophy of religion «. In his massive, albeit unfinished and fragmentary, True Intellectual System of the Universe of 1678 , the philosophy of religion is shown to centre around the three doctrines of a theism of a providential benign Deity, a strict ethical realism and a libertarian theory of action. ${ }^{8}$

Cambridge Platonist philosophy of religion as a whole left a decisive mark on the history of panentheism and panpsychism as well. As to panentheism, they have been credited with seeking to precipitate a »pantheism controversy « more than a century before the outbreak of the historic debate of that name in Enlightenment Germany. Theirs is a religious philosophy that may well be qualified as a »Spinozism of freedom «, 9 i.e. a system of thought that views God as informing and suffusing all of reality, while also emphasizing man's capacity for libertarian choice. Like the more well-known dispute between Friedrich

4 See the pioneering article by Thiel 1991: 79-99, and the perceptive chapter on the leading Cambridge Platonist's theory of human subjectivity in his monograph The Early Modern Subject. Self-Consciousness and Personal Identity from Descartes to Hume (Theil 2011: 67-71).

5 Even though the author's distinction between Cudworth's early emotionalism and mature intellectualism is almost certainly misguided, the general approach to Cambridge Platonist ethics in Gill 2006: 7-74, in terms of its secularism is sound. Theirs is an Enlightenment ethics which stresses the moral autonomy of the subject.

6 See Schneewind 1998: 194-214.

7 This has been established in the compelling study of Cudworth's ethics in Darwall 1995: 109-148.

8 Cf. Taliaferro 2005: 11-56, who hails the Cambridge Platonists as the founding fathers of the philosophy of religion.

9 On this description, generally applied to the various metaphysical systems of the German Idealists, see the illuminating account of early English idealism in Hedley 2000: 21-39. Somewhat anachronistically, this concept is a very adequate description of Cambridge Platonism, even though Spinoza's monism of substance is criticized only in the two major Cambridge Platonists' later works. The significance of their ancient theology with its emphasis upon divine all-oneness was first stressed in Assmann 2007: 110, who was the first to credit the group with anticipating key aspects of the later Pantheism Debate. 
Heinrich Jacobi and Moses Mendelssohn about the late Lessing's Spinozist creed, the controversies about Cudworth's account of Platonist, Patristic and Egyptian ancient theology pivoted around God as hen kai pain. As to panpsychism, it is thanks to their staunch resistance both to Cartesian dualism and Spinozist monism that the Cambridge Platonists are accorded a pivotal role in the history of this contentious doctrine. ${ }^{10}$ In his True Intellectual System of the Universe, Cudworth observed that the pre-Socratic »Strato's ghost had begun to walk of late «, 11 targeting two of the foremost western proponents of western panpsychism, namely the Dutch rationalist Spinoza, and one of his most gifted followers, i.e. the English physician turned metaphysician Francis Glisson. At the heart of panchchism or, as Cudworth chose to call it with another neologism of his own coinage, »hylozoism « is the notion of »living matter «, which is meant to render superfluous the belief in a transcendent creator God. In his magisterial outline of atheisms old and new, Cudworth sought to refute its hylozoist variety with the very first formulation of the now classic »combination problem « of many allegedly conscious atoms coalescing so as to form a higher animal organism or conscious human mind:

And to say, that these innumerable Particles of Matter, Do all Confederate together; that is, to make every Man and Animal, to be a Multitude or Common-wealth of Percipients and Persons as it were clubbing together; is a thing so Absurd and Ridiculous, that one would wonder, the Hylozoists should not rather chuse, to recant that their Fundamental Errour, of the Life of Matter, than endeavour to seek Shelter and Sanctuary for the same, under such a Pretence. ${ }^{12}$

However, it was Henry More, Cudworth's close friend and fellow Cambridge Platonist, who wrote the first major refutations of both Spinozist and Glissonian panpsychism. In his three works directed against Spinoza's Theological-Political Treatise and Ethics as well as Glisson's Treatise on the Energetic Nature of Substance, More built upon his earlier critique of Cartesian mechanism, which he had first put forward in his celebrated early correspondence with the French philosopher. In so doing, More developed a deeply original metaphysics of his

\footnotetext{
10 See the very apposite description of their position in the foremost historical account of Panpsychism in the West by David Skrbina 2017: 102-105; 320-322.

11 Cudworth 1678: 145 .

12 Ibid., 839. Cudworth's originality in the formulation of this stock argument against panpsychism is emphasized by Skrbina 2017: 321: »Needless to say, such a situation poses, if not a problem, then at least a very large question for any panpsychist. Perhaps the first to recognize the question, and to criticize panpsychism on the basis of it, was Ralph Cudworth.« An excellent exposition of Cudworth's critique of hylozoism is provided by Breteau 2006: 45-72.
} 
own which may broadly be characterized as panentheist and panpsychist in outlook. God, More argued both in his early rebuttal of Descartes and in his late critiques of Spinoza and Glisson, is an infinitely-extended creative mind endowing all of reality proceeding from its fullness with a first rudimentary life of its own. Only if we are prepared to grant extension to God and life to matter may we account for causality and the communication of motion by one body to the other. ${ }^{13}$

\section{The Conundrum of Cartesian Causality_Vitalism in the Correspondence with Descartes}

It is to remedy two perceived aporiai of Descartes' philosophy of nature that More provides an early draft of a panentheist and panpsychist metaphysics in his correspondence with the French rationalist. ${ }^{14}$ The first is that of divine action. In order for God to communicate motion to inert matter in the beginning, he needs to share with it its extension. He must, therefore, be viewed as an infinite incorporeal extension coextensive with finite corporeal extension. The second conundrum bears upon the concept of motion itself which, as a mode, cannot pass from one substance to another. Instead, all of reality must be endowed with a certain power of its own by which it can set itself in motion.

Throughout their correspondence, More bestows lavish praise upon the Frenchman whose natural philosophy surpasses all its rivals past and present. However, despite the admiration in which he holds Descartes' thought, there are a few »minor details « (paucula) on which More begs to differ from him. ${ }^{15}$ These »minor details« all bear on the core of Descartes' rationalism,

13 My appraisal of More's early and mature metaphysics is throughout deeply indebted to the detailed expositions of his thought in Reid 2012, and Leech 2013.

14 More 1679: II/2, 227-271. The Correspondence has been recently translated into English by myself and published in the online sourcebook of Cambridge Platonism: http://www. cambridge-platonism.divinity.cam.ac.uk/view/texts/diplomatic/Hengstermannı679C. There are several fine studies devoted to More's early enthusiasm for and gradual disenchantment with Descartes. The definitive overviews of the philosophical controversy and the text corpus of the correspondence are provided by Gabbey 1982: 171-249, and id. 1903: 628-642. See also the lucid chapter on More's critical reception of Descartes, in: Pacchi 1973: 3-48. Of the special issue of Les Études Philosopiques 2014/1 devoted to More's Cartesian writings, the papers by Anfray (2014), and by Leech (2014) are particularly important for the following précis of the debate. The charge of atheism which More levelled at Descartes in the 1670 s revolves around the latter's denial of divine extension first discussed in the original correspondence of 1649/50.

15 Epistola prima H. Mori ad R. Cartesium (Op. omn. II/2, 234). 
notably his dualism of thought and extension and the question of how God, or any other incorporeal substance, can act upon matter and body without sharing the latter's defining attribute of extension and being present to it in some way. ${ }^{16}$ In response to what he views as a fundamental weakness of the admired Frenchman's ontology and philosophy of nature, More, in the first exposition of his landmark doctrine, suggests that God must be viewed as »extended in his own way«:

Firstly, the definition which you give of matter or body is far broader than is warranted. For God also seems to be an extended substance, as do angels and indeed every thing subsisting through itself. Hence, extension is apparently coterminous with the absolute essence of things, although the latter may differ according to the differences between the essences themselves. I view God as being extended in his own way on account of his omnipresence, occupying as he does the whole fabric of the world and each of its particles in an intimate fashion. How else could he impress motion upon matter, which, as you yourself concede, he did at some point and which he does to this day, unless he touches, or had at least at some point touched, the matter of the universe from close up? He could not have done so at any time had he not been present everywhere and occupied every single place. Hence, God is extended and expanded in his own way, and therefore is an extended substance. ${ }^{17}$

More's argument is remarkable for its audacity. It calls for a new ontology whose first axiomatic tenet, as he states dogmatically, is the extension of all of being or substance as »coterminous with the absolute essence of things «. ${ }^{18}$ Its theistic rationale is God's creative agency in imparting motion to matter viewed as entirely immobile by itself in Cartesian physics. If and only if God is, or was at least once, present in all places, can he »touch«, or have touched at least once, the atoms constituting the reality of extension. More finds warrant

16 As a consequence, Descartes, not surprisingly, was quite explicit in remarking in Responsum R. Cartesii ad Epistolam Primam H. Mori (Op. omn. II/2, 240) that, notwithstanding More's protestations to the contrary, his well-argued paucula were far from peripheral to his project of rationalist physics: »Moreover, I do not admit what you grant me in your extraordinary kindness, namely that my other opinions might well stand even if those about the extension of matter were refuted. For it is one of the principal and, in my view, most certain foundations of my physics, and I confess that no other reasoning could ever satisfy me in physics proper than one involving a so-called logical or contradictory necessity (excepting only those things which can be known from experience alone such as the fact that there are only one sun and moon around this earth and the like).«

17 Epistola prima H. Mori (Op. omn. II/2, 234-235).

18 This statement is particularly noteworthy as More in Epistola Secunda H. Mori (Op. omn. II $/ 2,243$ ) states that »the root and essence of all things lies hidden deep in eternal darkness «. 
for his ontology of spiritual extension in the ancient theology represented by the Roman poet Virgil whose cosmological aperçu »The spirit within nourishes, and mind instilled throughout the living parts activates the whole mass, and mingles with this vast body ${ }^{19}$ interpreted by the author as a nod to the Platonism of the imperial age, contains in a nutshell his own key conviction of an extended God omnipresent in matter as the source of its motion. In contradistinction to corporeal extension which is defined by its inability to penetrate or be penetrated by other bodies, spiritual extension penetrates and is penetrated by other spiritual and corporeal extensions alike. Spiritual extension, in turn, is either infinite or finite. Whereas finite spiritual extensions such as the human or the angelic mind may expand or contract, occupying larger or smaller bodies and places at will, ${ }^{20}$ God's extension is, by definition, infinite, hence admitting of neither. Nor does divine extension entail the divisibility of his substance. Instead, God's infinite extension is such that he occupies every single place $»$ in his entirety«:

Besides, God, insofar as the human mind comprehends God, is everywhere in his entirety. He is present in all places and all spaces as well as in each point of space in his whole essence. However, it does not follow that he has parts external to each other or that, by implication, he is divisible, even though he occupies all places very closely and tightly without leaving any gaps in between. Hence, I

19 Virgil, Aeneid, VI 726-727, quoted and discussed in Epistola prima H. Mori (Op. omn. II/2, 235).

20 Cf. Epistola Secunda H. Mori (Op. omn. II/2, 243): »Notwithstanding, I hold that there is another equally real extension, which is not so well-known, let alone common knowledge in the schools. It possesses both different limits and shapes in angels and human minds which the latter, angels and minds, can change at will. While remaining one and the same substance, they can contract or re-expand to those bounds. « See also ibid., (II/2, 245): »For I deny that extension belongs to a body, insofar as it is a body, but rather insofar as it is a being or at least a substance.« More went on to call this variable extension the »essential spissitude« of finite spiritual extension. In his principal philosophical work The Immortality of the Soul I 2,11 (More 1987: 28), it is defined as a fourth dimension which distinguishes it from three-dimensional corporeal extension. The former spiritual dimension, he avers, is understood by the mind with the same ease and clarity as the latter three are perceived by the senses: »And as what was lost in Longitude was gotten in Latitude or Profundity before; so what is lost here in all or any two of the dimensions, is kept safe in Essential Spissitude: For so I will call this Mode or Property of a Substance, that is able to receive one part of it self into another. Which fourth Mode is as easy and familiar to my Understanding, as that of the Three dimensions to my Sense or Phansy. For I mean nothing else by Spissitude, but the redoubling or contracting of Substance into less space then it does sometimes occupy. And Analogous to this is the lying of two Substances of several kinds in the same place at once.« 
acknowledge the divine presence or amplitude, as you call it, to be measurable, but I deny that he is divisible in any way. ${ }^{21}$

However, infinite incorporeal extension may, by virtue of the »ubiquitous reiteration of its complete and total essence $\ll^{22}$ or creative spatial omnipresence, act upon any finite spiritual or material extension occupying any place within its own infinity, »touching « it and thereby imparting motion to it. More provides a graphic example of possible divine action in his rebuttal of Descartes' denial of a vacuum consequent upon the latter's identification of body and extension. Whereas a vessel, on the principles of Cartesian physics, must collapse once the bodily extension between two opposing sides has been removed, Morean physics allows for a possible divine intervention preventing them from meeting:»For if God impresses motion upon matter, as you have shown earlier, can he not press against it, preventing the sides of the vessel from meeting? However, it is a contradiction to say, you argue, that the sides of a vessel are distant from one another without there being anything between them. «23

»Motion « of which God is the first source poses another major problem of which Cartesian physics, according to More's early critique, is ill-equipped to provide a philosophically satisfactory account. More, for one thing, takes exception to Descartes' very concept of motion as a merely relative change of place of two adjacent bodies. Firstly, its resultant reciprocity leads to several absurd consequences. Thus, on Descartes' principles, a tower must be said to undergo motion whenever the west wind passes by it. Likewise, and even more implausibly, one person sitting still as another runs away from them, breaking out in sweat as a consequence, must be viewed as moving at the same speed. ${ }^{24}$ Secondly, and arguably worse, Descartes' definition fails to do justice to what More views as the defining characteristic of motion, namely the active power by which a spirit, whether divine, human or non-human, impels matter particles otherwise wholly inert and inactive. On closer inspection, this power of motion renders its very concept even more confusing. As the lowest of the categories, it should neither be able to act upon a substance nor pass from one to another without inevitably vanishing in the process: $\gg$ Finally, I am completely baffled when I consider that a thing as tiny and as vile as motion, which is also capable of being separated from its subject and passing to another, and which is of so frail and so transient a nature that it would cease to be at once if it

\footnotetext{
21 Epistola Secunda H. Mori (Op. omn. II/2, 245).

22 Ibid. (II/2, 246).

23 Epistola Prima H. Mori (Op. omn. II/2, 235).

24 Epistola Secunda H. Mori (Op. omn. II/2, 247-248).
} 
were not for a subject sustaining it, should nevertheless stir its subject up so potently and impel it here and there so forcefully.« ${ }^{25}$ More's far-reaching solution to the aporia of Cartesian causality consists in a sketch of panpsychist cosmology that is closely linked to his panentheism of a spatially-extended infinite Deity. There is, in reality, he avers, no transfer of motion whatsoever. Instead, body and motion must be conceived of in analogy to mind and thought with one body exercising its own inherent power in setting itself in motion when occasioned to do so by another hitting it. The body's inherent power or »life « is not yet sensation, but rather a rudimentary kind of self-presence or protomentality which, as is required by its role in More's theory of natural causality, enables it to engage in a certain degree of self-motion. Ontologically, material extension is the »last and lowest shadow and image of the divine essence " from whose infinite extension it derives its own motion in creation:

I, for one, am more inclined to assume that there is no transfer of motion whatsoever. Rather, on account of the impulse of one body, another body is, as it were, awakened into motion, just as the soul is awakened into thought on this or that occasion. Instead of receiving motion, a body stirs itself into motion on being alerted by another body. And, as I have said before, motion is to body what thought is to mind, that is to say, neither of them is received from without, but both proceed from within the subject in which they are to be found. And in fact every so-called body is also alive in a mindless and befuddled way, since in my view it is the last und lowest shadow and image of the divine essence which, I hold, is most perfect life. However, it is devoid of all sense and animadversion. ${ }^{26}$

All of reality is a »shadow and image« of God's own archetypal »perfect life « with which it, therefore, cannot but share its defining characteristic. Inanimate being is, hence, ruled out as incompatible with the notion of creation viewed as the procession of reality from the supreme divine life. Instead, self-motion is intrinsic to reality. ${ }^{27} \mathrm{As}$ a $» k i n d$ of dark life «, matter per se is not primarily

25 Epistola Tertia H. Mori (Op. omn. II/2, 256).

26 Ibid. As is observed by Reid 2012: 246 , More's theory of causality may be branded an idiosyncratic kind of occasionalism or »occasional causation « which the author defines as follows: »Whereas ordinary transeunt efficient causation means that one object $A$ simply produces a certain effect on another object $B$ by means of the exercise of its own intrinsic power, occasional causation will take place when one object $A$ induces another object $C$ to produce an effect on $B$ by its own.« Thus, whereas in Malebranche's more well-known variety, it is God who is the source of all motion, More's attributes agency to every body qua body. His, therefore, is a cosmos of nearly infinitely many agents each of which, by its very nature, possesses the capacity for some rudimentary self-motion.

27 In response to Descartes' scathing criticism of his notion of living matter, More, in his Responsio ad Fragmentum Cartesii (Op. omn. II/2, 271), provided an illuminating explanation of the metaphor of nature as a »shadow« of the Deity. Its meaning is twofold. It 
an »extension of its parts«, but rather a »constant motion« initially given to it and subsequently guided by God's ubiquitous creative intellect which »instilled throughout the living parts activates the whole mass, and mingles with this vast body.«

Throughout his Correspondence, More closely links God's spatial ubiquity and nature's universal animation, viewing God's creative agency, exercised in every single place of his infinite extension, as a benign communication of life and motion. While following the logic of his early trialism of extension in disagreeing with Descartes and assuming the possibility of a vacuum, More is nevertheless careful to deny its reality on theological grounds. Instead of leaving places devoid of its beneficent self-communication, »the divine fecundity«, More instead states as a theological first principle of his Christian Platonism, »is not idle anywhere. It has produced matter in all places without leaving even the minutest of gaps. ${ }^{28}$ God's spatial omnipresence is, hence, inextricably linked to his creative agency by which he everywhere produces the »dark life« of matter as his own »shadow and image«. His creative agency is conceived of in the univocal terms of More's own hylemorphist theory of human action. For one thing, he avers, God's life-giving omnipresence is the ontological sine qua non of the existence of libertarian agency in the first place. It cannot but seem all but inexplicable on the principles of rigid Cartesian mechanism: »How does the $\alpha \dot{\tau} \tau \xi \xi v \sigma ı v$, of which we are conscious in ourselves, come to be? « ${ }^{29}$ For an-

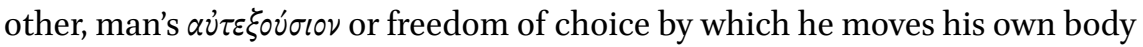
by virtue of its animal spirits and shapes the corporeal reality within and without furnishes the closest analogue to God's own life-giving agency in the world:

I wonder, therefore, whether a philosopher should not acknowledge that there is in the whole fabric of things some incorporeal substance which can nevertheless, as bodies do on one another, impress on some body all or at least most

expresses 1) the ontological dependence of the image upon the archetype and 2) a certain ontological kinship. In so doing, he also addresses the inevitable, yet possibly misleading, use of metaphorical language in all discussions of panpsychism: »Besides, there cannot be any deceit hidden in the use of metaphors and similitudes as long as we keep in mind that things are not designated by their proper names, but by figurative ones. Hence, in saying that matter or the universal body of the world was, as it were, the shadow of the divine essence, I did not mean to say they were a shadow in reality. For the meaning of this metaphor is not that it is a shadow in actual fact, but that it depends upon God as does the shadow upon the body. Further, just as a shadow reflects some image of the body, albeit a very obscure and base one, there are in body or matter some blind and faint traces of the divine essence. However, since the latter, as I have said, is most perfect life, the analogy itself requires that matter is not wholly deprived of the image of life."

28 Epistola Secunda H. Mori (Op. omn. II/2, 246).

29 Ibid. (II/2, 246). The concept used is the Stoic technical term for »free will«. 
corporeal properties such as motion, shape and the structure of its parts. Nay more, since this clearly holds true of motion and rest, may it not also add to it whatever is consequent upon motion? May it not divide and join, disperse and bind together, give shape to particles and arrange them after that, make them rotate or move in any other way and stop them again as well as all other such things as necessarily give rise to light, colour and other sense impressions of that kind, as your excellent philosophy has shown? ${ }^{30}$

Mores's early doctrine of divine agency and causality by which he seeks to remedy two key aporiai of Descartes' metaphysics and physics posits an archetypal spirit of infinite extension and creative omnipotence which shapes the cosmos by »touching « it itself and by guiding and directing the infinitely many material self-movers inhabiting it. In his mature critique of Descartes' unorthodox follower Baruch de Spinoza, whom More, upon reading his Theological-Political Treatise in 1677, identified as the most astute of atheists, God's infinite extension and ubiquitous life-giving agency are identified with absolute space and the spirit of nature respectively.

$30 \quad$ Ibid. Descartes' comments on his critics' reflections upon God's substance and agency are highly revealing. On the one hand, he acknowledges in Fragmentum Resp. R. Cartesii ad Epist. Tertiam H. Mori (Op. omn. II/2, 268) that More's doctrine of divine agency is based upon his own physical axiom of the preservation of the amount of motion originally imparted to the world in creation: »However, the moving power may well be that of God himself preserving the same amount of transfer in matter which he put into it at the first moment of creation.« Moreover, while not sharing More's ontological conclusions, Descartes, in Responsum R. Cartesii ad Epistolam Secundam H. Mori (Op. omn. II/2, 252) also concurs with his view of the quasi-univocity of divine and human action expressed in hylemorphist terminology: »And while I think that there is no mode of action belonging to God and his creatures univocally, I must confess that I cannot find in my mind any other idea representing a mode in which God or an angel can move matter than the one exhibiting to me the mode in which I am conscious of being able to move my body by my thought.« On the other hand, however, Descartes' caveat that the resultant doctrine, as is clear from its very language, may be seen as close to Plato's and Plotinus's notion of the world soul is evidently far from ill-founded. It is, as he points out in Fragmentum Resp. R. Cartesii ad Epist. Tertiam H. Mori (Op. omn. II/2, 268), one of the reasons for his denial of spiritual extension: »I was afraid that I might seem to endorse the view of those who consider God the world soul united with matter.« 


\section{Divine Space and Living Nature-The Panentheism and Panpsychism in the Critique of Spinoza}

\subsection{Spatial Panentheism: God as Infinitely-Extended Mind}

At the heart of More's critique of Spinoza are what he chooses to call »twin columns of « his adversary's »atheism, namely that necessary existence pertains to substance as substance, and that there is but a single substance in the universe ${ }^{31}{ }^{31}$ In his critique of Spinoza's rationalist system, More vacillates between a strict first reading, viewing it as naturalism and reductive materialism, and a somewhat more charitable second one, branding it »hylozoism « or panpsychism. Either the single substance erroneously viewed as existing of necessity is matter per se or it is matter endowed with a rudimentary life of its own. Spinoza's misguided materialist ontology is throughout shown to spring from his inadequate epistemology which fails to do justice either to God's goodness, as intuited by what More calls the soul's »boniform faculty«, or the distinction between imperfect material and perfect divine extensions, as perceived by the senses and understood by the intellect respectively. ${ }^{32}$

31 Demonstrationis Duarum Propositionum ... Confutatio, title (Op. Omn. II/2, 615). The Confutatio (ibid., 615-635) of Spinoza's principal philosophical work, the Ethics, is inarguably the most important of More's three writings against Spinoza. However, his undulyneglected earlier refutation of the Theological-Political Treatise (ibid., 563-601) contains philosophical points crucial to More's own anti-Spinozist panentheism and panpsychism. A third work is his Scholia In Epist. Ad V.C. (ibid., 602-614) in which More provides critical comments on the Opera Posthuma, which he had purchased in London shortly after his refutation of the Treatise. Most importantly, it contains his refutation of the Spinozist panpsychism of the Cambridge metaphysician Francis Glisson. See pp. 180-185 below. There is an English translation of the Confutatio by Alexander Jacob with a helpful introduction and notes: Alexander Jacob, Henry More's Refutation of Spinoza, Hildesheim/ Zurich/New York: Olms, 1991. My English translations of the Ad V.C. Epistola altera and the Scholia are accessible online in the Sourcebook: http://www.cambridge-platonism. divinity.cam.ac.uk/view/texts/diplomatic/Hengstermanni679A. An exhausting account of the historical background of More's critique of Spinozism, including the link between Cambridge Platonism and liberal Dutch theology, is provided by Colie 1964: 183-219, and 1957: 66-93. See also Hutton 1984: 181-200, viewed by the author herself as »no more than a footnote to these studies« by Colie (ibid., 194 n. 1). However, Hutton's essay contains an illuminating comparison between Spinoza's and the Cambridge Platonists' divergent concepts of divine revelation.

32 This two-fold approach to Spinoza's metaphysics was first noted by Leech (forthcoming) on whose compelling reconstruction of the debate between the Dutch and the English rationalist the following exposition relies and builds throughout. See also the author's earlier account in Leech 2013: 199-227. Cf., moreover, the excellent new article by Reid 2013: 764-792. Apart from Leech's and Reid's important recent research work, More's critique, despite its historical and systematic significance, has received only scant scholarly 
In his critique of biblical prophecy in the Tractatus, ${ }^{33}$ Spinoza views revelation as originating solely in the Hebrew prophets' vivid imagination. Its sole object is ethical obedience, rather than metaphysical truth. The truth of the prophets' imaginative visions is one of »moral certainty « alone and is borne out by their own probity and by God's signs granted to them in confirmation of their mission. While More concurs with his adversary that the prophets were virtuous seers who were endowed with great imaginative power and granted extraordinary signs by God, he views prophets like Isaiah and Ezekiel as philosophers of the highest calibre. The chief power by which they acquired the most sublime of truths about God, the soul and the world was their »boniform faculty ${ }^{34}$ or, as More chooses to term it in his Ad V.C. Epistola altera, a »natural sagacity $\ll^{35}$ or an »internal sense $\ll^{36}$ It is the power by which the soul, prior to any discursive reasoning, grasps or »touches « the infinity of God's universal goodness in indisputable intuitive awareness. The soul's boniform vision is one of a world proceeding from and suffused by God's disinterested creative beneficence. At the moment of immediate insight, God himself acts upon the soul as its principle and form, allowing it to share in his own beneficent omnipresence in existential union with it. In an early work, More provides a memorable description of his philosophical mysticism:

But I say that a free divine universalized spirit is worth all. How lovely, how magnificent a state is the soul of man in, when the life of God inactuating her, shoots her along with himself through Heaven and Earth, make her unite with, and after a sort feel herself animate the whole world, as if she had become God and all things? This the precious clothing and rich ornament of the mind, farre above reason or any other experiment. This is to become Deiform, to be thus

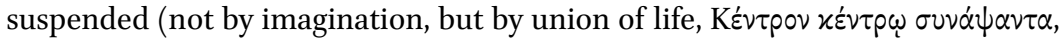
joyning centres with God) and by a sensible touch to be held up from the clotty dark Personality of this compacted body. ${ }^{37}$

As in More's early hymn to the pinnacle of the soul's experiential, yet rational, vision of God, the prophets' »sagacity« and »internal sense« of God is

attention so far. Of the two earlier articles by Becco 1978: 103-119, and Schütt 1981: 19-50, the former provides an excellent interpretation in terms of More's defence of divine and human agency, while the latter is largely an exercise in the logic of Spinozist monism.

33 Theological Political Treatise 1-2 (3, 15-44 Gebhardt).

34 Enchiridion Ethicum I 2,5 (Op. Om. II/1, 12). See my comprehensive exposition of Cambridge Platonist epistemology in Hengstermann in print $b$.

35 Epistola altera 20 (Op. omn. II/1, 574).

36 Ibid.

37 Second Lash of Alazonomastix, Cambridge: Printers to the University of Cambridge, 1651,43 . 
described in terms of divine and human double-agency in his mature critique of Spinoza. Theirs is a knowledge of absolute certainty and indubitability in all matters of speculative divinity. Such, in fact, is the internal certainty attached to the prophets' boniform vision that it even renders superfluous any exterior warrant, including divine signs, however impressive: »I reply that even though there usually tend to be external signs, prophets may nevertheless be equally certain without them because of a higher principle dwelling in their hearts, namely the most inward operation of the divine spirit that stirs a faith stronger than all imagination, reason or external sign. $\ll^{38}$ The knowledge granted to the prophetic soul is that of God's first attribute, his universal and disinterested goodness. By virtue of their »natural sagacity« which is superior to reason and sense, the prophets are given »indubitable knowledge of « a »God « who creates the world and intervenes in its history as a benign agent, as laid down in the Holy Writ: »For there is in all humankind a certain and infallible sagacity of mind by which they derive indubitable knowledge of God from such historical narratives and come to worship his justice, power and goodness. « 39

It is on the basis of the soul's boniform vision of the ens perfectissimum as a supremely good and benign agent that More subjects Spinoza's definition of God as »absolutely infinite being, i.e. substance consisting of infinite attributes, each one of which expresses eternal and infinite essence $\ll^{40}$ to detailed criticism. The bone of contention is the »absolute « by which the Dutch rationalist qualifies God's infinity, expressly rejecting a Divine that is »only infinite in its kind « as unduly restricting it and denying to it any number of possible attributes expressing positive being and power. ${ }^{41}$ In a two-fold argument, More rehabilitates the Cartesian definition of God as the »supremely perfect being ${ }^{4}{ }^{42}$ which, he avers, rules out »absolute« infinity as an adequate divine attribute. First, in an ad hominem argument, »absolute « infinity is shown to imply the infinity of all divine attributes, including the supreme moral ones which Spinoza is at pains to expose as merely imaginary and anthropomorphist in nature. Thus, Spinoza, despite himself, is compelled to acknowledge the absolute moral perfection of the one absolutely infinite substance: »For, an absolutely infinite being altogether implies infinite perfection, and infinite perfection absolute omnipotence, omniscience, and foresight of all things, which do not please Spinoza's judgement. « ${ }^{43}$ Secondly, God's moral perfections, on the

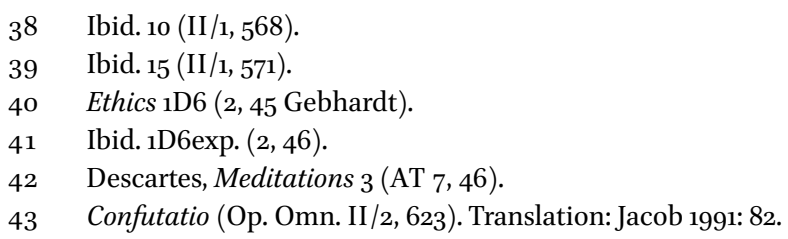


principles of More's Christian Platonism, serve as the chief criterion of all of his characteristics. If and only if infinity expresses a moral perfection can, and must, it be predicated of the most perfect being. The suigeneris of divine infinity upon which More is careful to insist in opposition to Spinoza's absolute is its goodness or the »essential sanctity and purity of the divine Majesty « by which it creates and saves all of reality. At the heart of the notion of the ens perfectissimum expounded in More's critique of Spinoza, therefore, is its infinite moral perfection to which all of its other perfections must be viewed as subservient in its defining creative and salvific agency and by which it cannot but transcend all of reality beneath it:

Hence, absolute infinity in God must not be understood in such a fashion as if it were not an infinity of his own kind (sui generis) and an infinity corresponding to his most absolute perfection. For there is a certain essential sanctity and purity of the divine majesty by which he is different and distant from all the rest of things by his very kind, as it were (toto quasi genere). It is this sanctity which this impure sophist tries to violate with such zeal and temerity when confusing the divine nature with the nature of created things. No infinity, therefore, is denied to God which expresses perfection, but that alone which involves imperfection. And whatever is perfect in the essence of creatures, as long as it pleases God, must be referred to him as the source and principle which. While not encompassing them formally, he encompasses the essences and perfections of all created things eminently and causally. ${ }^{44}$

The God of More's anti-Spinozist writings is both the Platonic idea of the good and the perfect mind expressed in Cartesian language. As the archetypal mind, he is not identical with the formal or actual reality of subsequent creation, but its eminent or causal archetype beyond it. As creative goodness, More's Platonic God chooses to share his cosmic vision with man and the world at large. His supreme goodness by which he ungrudgingly communicates the riches of his being to all of reality constitutes the emphatic suigeneris by which God transcends the latter both in ontological rank and supremely moral power.

Throughout his system, Spinoza fails to do justice to this transcendence of holiness by which God, as the soul intuits by virtue of the highest of its epistemic powers, is »distant and different« from the world. Instead, »confusing the divine nature with created nature «, he erroneously identifies God with matter viewed as mindless mechanism at worst and as generic life at best. On More's materialistic first interpretation of his adversary's substance monism, Spinoza, despite all his protestations to the contrary, is an atheist who denies the existence of God altogether. Instead, he posits matter as the sole 
deity. Spinoza's erroneous naturalist ontology of a divinized mindless matter is shown to originate in an egregious epistemological error. In an in-depth critique of proposition 15, More rejects Spinoza's argument that it is one and the same extension perceived by sensation and imagination as finite, composed of parts and divisible and understood by intellect as infinite, without parts and indivisible: »As if, indeed that which is everywhere apprehended as divisible by the senses, can rightly and truly be conceived of by the intellect as indivisible, all the particular things of the world, that is, the modes of the material world be divisible, and yet all the matter of the world everywhere, insofar as it is substance, be indivisible. ${ }^{45}$ Spinoza erroneously conflates God with the material extension of sense perception and imagination, thereby attributing to him its many imperfections, including its divisibility. Not only is God, as material extension, inevitably subject to the chaos of purely mechanistic motion and rest, but his thought likewise becomes divisible. Dispersed throughout all of animate matter, it is not the unified one of perfect indivisible intellection, but a disjoined many of a great number of consciousnesses of varying complexity. On More's more charitable second reading of Spinoza's substance monism as »hylozoism « or panpsychism, God is not mere matter, but thought as well. However, God's thought is an inferior cogitation spread out throughout the infinitely many living beings brought about by the random motion and rest of his infinite extension. Since each of the modes of God's extension, on the principles of Spinoza's parallelism, is a mode of divine cogitation as well, divine cogitation must be literally »asinine« in asses and »leaden« in lead:

Since, therefore, stones, lead, dung, an ass, a toad, a louse and all things of that sort are individual things, it is necessary that they be modes of the attributes of God and their expressions in a certain and determinate manner. Moreover, since besides substance and modes there is nothing, and modes cannot be without substance, it is clear that the substance of God is the substance of stones, lead, dung, an ass, a toad, and a louse, and those extended things modes of divine extension and those thoughts modes of divine thought, so that the God of Spinoza thinks in an ass as an ass, in a toad as a toad, in a louse as a louse, and indeed in a stone, lead and dung as stone, lead and dung. ${ }^{46}$

45 Ibid. (II/1, 620). Translation: ibid., 73.

46 Ibid. (II/1, 619-620). Translation: ibid., 71 (modified). Cf. ibid. (II/1, 627), where More includes his adversary himself in a satirical climax of alleged subjects of divine thought, highlighting the incompatibility of hylozoism with an adequate definition of the ens perfectissimum: »Whence, if the substance which is God, or a Being supremely and absolutely perfect, is nothing besides matter, which Spinoza, however, wishes, this God of Spinoza will think as a goose in geese, as an ass in asses, as a toad in toads, as louse in lice, as a tortoise in tortoises, as a man in men, as a fool in fools, as a maniac in maniacs, as Spinoza in Spinoza ( translation: ibid., 95). 
The many living beings and animate objects, each of which is viewed by Spinoza as a mode of divine extension and cogitation alike, are altogether ignorant of the mind processes of their fellow creatures. They, hence, fail to coalesce in one unified consciousness greater than themselves, let alone perfect in its range and scope. The multiplicity of consciousnesses in Spinozist hylozoism cannot but fall short of the unity of supreme cogitation worthy of the ens perfectissimum.

Still, although he lambasts Spinoza's erroneous reasoning, More is nevertheless prepared to credit his adversary with certain insights. In particular, Spinoza, for all his enthusiast fancy and materialist error springing from it, is shown to have had at least a faint inkling of the sui generis divine spatial extension of More's own mature metaphysics ${ }^{47}$ which, astonishingly, the English rationalist expressly qualifies as prophetic in character. ${ }^{48}$

Spinoza therefore rages and raves, and does not philosophize acutely or soundly. However, in this philosophical rage there seems to me to have sprung up by itself, from the heat of this tumultuously agitated mind - just as it sometimes occurs to the delirious to divine in a certain manner and prophesy - the form of infinite and indivisible extension. There is indeed a certain substance of this sort, infinite, indivisible and extended with unitary extension, which is absolutely indivisible and infinite, which, through what rage I do not know, has sprung up in Spinoza's mind here. That this is indeed not matter is in fact certain — of which more later. ${ }^{49}$

Spinoza's prophetic insight revolves around the two unorthodox Cartesians' shared notion of a God who is not only perfect cogitation, but perfect extension as well. Crucial to Spinoza's and More's own line of reasoning is the Cartesian

47 Besides the chapters devoted to it in Reid 2012: 103-139, and in Leech 2013: 123-143. More's historic doctrine of absolute space, generally held to have influenced Isaac Newton's, is the subject of several in-depth book chapters and articles. Cf., above all, the classical exposition by Koyré 2008: 78-94. Of the many essays devoted to Morean space, the one by Boylan 1980: 395-405, which is dedicated to the two principal mediatory entities in More's panentheist metaphysics, is particularly relevant to the following account. Though building upon his more comprehensive exposition in his Enchiridium Metaphysicum of 1679, to which he repeatedly refers his reader, the epistemological argument for divine absolute space in the Confutatio adds quite significantly to the most celebrated of Morean doctrines.

48 Not only is it extraordinary that More should credit his as formidable a philosophical a foe as Spinoza with the gift of prophecy, but it is also in keeping with the epistemology of his late critiques of enthusiasm and materialism. Every soul, however impure and corrupt, possesses a boniform faculty and is, hence, open to the vision of God's spatial infinity suffused by his omnipresent creative and salvific goodness.

Confutatio (Op. omn. II/1, 621). Translation: Jacob 1991: 74 . 
axiom »that nothing is the modification of nothing « ${ }^{50}$ This axiom by which Descartes himself had established the existence of the second substance of extension is the pivot of More's argument for the necessary existence of an infinite divine spatial extension. Whereas Spinoza, implausibly, assumes that one and the same extension may at once be perceived as divisible and mobile and understood as indivisible and immobile, More instead insists that equal weight be placed upon the perception and the intellection of extension. The two extensions defined by contradictory predicates must, hence, be viewed as the attributes of two substances equally different in nature. Sensation and intellection reveal one extension that is mobile and »discerpible and impenetrable « and another that is immobile and »indiscerpible and penetrable« respectively. ${ }^{51}$ The former is the defining attribute of finite matter, the latter that of infinite spirit. Whereas Spinoza agrees with Descartes in identifying extension with matter tout court, More, from his early correspondence with the French rationalist in the late 1640 os to his late critique of Spinoza in the 1670s, distinguishes sharply between an imperfect extension that is the object of sensation and imagination and a perfect extension that is the object of intellection: »I say, however, that there is an extended substance which it would be madness and delirium to consider as being composed of parts. That is, that immobile extension distinct from mobile matter which I have demonstrated in the Enchiridion Metaphysicum. «52 In More's principal metaphysical work, the demonstration or intellection in which the necessary existence of infinite space is established takes the form of a conceivability argument modelled upon Descartes' metaphysical doubt. Even when abstracting from all attributes and modes of cogitation and extension, the I is shown to be unable not to grasp an infinite extension in which it cannot but imagine itself to be situated in the very act of meditative doubt and abstraction:

50 Descartes, Principles of Philosophy I $5^{2}$ (AT 7, 25), quoted ibid. (II/1, 626). In his Scholia in Fragment. Respons. R.C. (Op. Omn. II/2, 269), a later comment on his own original correspondence with the French philosopher, More is careful to emphasize the axiom common to his and Spinoza's metaphysics of the extended Divine, referring the reader to his late metaphysical chef-d'oeuvre: »Certainly, if the Cartesians hold on to these principles - and Spinoza himself is most adamant that there is no property or predicate of nothing - then it can clearly be demonstrated that there is an incorporeal substance distinct from matter which is extended in some way. I have provided detailed proof in my Enchiridium Metaphysicum, chs. 6-8.«

$5^{1}$ These are the defining attributes of body and spirit in More's Immortality of the Soul I 3,2 (p. 30 Jacob).

$5^{2}$ Confutatio (Op. Omn. II/1, 61). Translation: Jacob 1991, 61. 
I shall only observe, incidentally, that anyone who thinks his mind can be nowhere, may test his powers of thinking, and after he has abstracted himself from all thought or sense of his body, and fixed his mind on the idea of indefinite or infinite extension alone, and at the same time perceives himself to be some particular thinking thing, let him test, I say, whether he can in any way avoid perceiving himself at the same time to be or, at least, to be able to be somewhere within this very immense extension and to be surrounded everywhere by it. ${ }^{53}$

As well as establishing the reality and necessity of infinite spiritual extension which the I cannot conceive as non-existent, More's anti-Cartesian and antiSpinozist conceivability argument also proves the contingency of indefinite or finite material extension. Infinite spatial extension can clearly be conceived by the I as entirely devoid of body and matter, i.e. as a vacuum, whose possibility More had established in his early critique of Cartesian physics. Bodily matter is thereby shown both to be distinct from extension and strictly contingent. Moreover, the necessity by which infinite extension and spirit is distinguished from contingent finite matter strongly points to its divine nature. It is further corroborated by some twenty attributes which absolute space shares with the God of classical theism. Once again invoking the Cartesian principle »that nothing is the modification of nothing $«, 54$ More insists that, far from banning the Divine from the world, it proves its omnipresence in it: »And so, by that very door by which the Cartesian philosophy«, embraced and carried to the inevitably atheistic upshot of its mechanism by Spinoza, »is seen to wish to exclude God from the world, I, on the contrary (which I am confident will attend me with the happiest success) strive and strain to bring him back. «55 More's argument in his Enchiridium Metaphysicum ends in an enumeration of the characteristics common to God and space: »Of which kind are those which follow, which metaphysicians specifically attribute to First Being. Such as one, simple, immobile, eternal, complete, independent, existing from itself, subsisting by itself, incorruptible, necessary, immense, uncreated, uncircumscribed, incomprehensible, omnipresent, incorporeal, permeating and encompassing everything, Being by essence, Being by act, pure Act. «56

Infinite immobile space, as distinct from finite mobile matter, is a key concept in More's Confutation. For one thing, it serves as a principle of individuation that is meant to buttress his traditional doctrine of substance pluralism. Individuation, in More's mature ontology, is not necessarily due either to

53 Enchiridium Metaphysicum 27,10 (Op. Omn. II/1, 312). Translation: Jacob 1995: I, 107.

54 Ibid., 8,7 (II/1, 167). Translation: ibid. 57.

55 Ibid. Translation: ibid.

56 Ibid., 8,8 (II/1, 167). Translation: ibid. 
attribute or mode, as Spinoza holds in his argument for monism, but to place. $»$ Real distinction $\ll, 57$ conceived as the spatial separation of individual substances sharing one or both of their defining attributes, enables him to eschew monism and hold on to an ontological pluralism of self-movers. For another, More views immaterial extension as the mode of divine omnipresence. Thus, whereas mobile material extension cannot be predicated of God as the most perfect being, immobile immaterial extension is the mode of his creative and salvific ubiquity whereby God »touched «, and continues to »touch «, the extended minds inhabiting the infinite space of his archetypal intellect. Such is the God of the boniform vision that he gives life to responsible agents who possess the ability either to obey or disobey the »laws « of his universal goodness inscribed into their reason. Moreover, once they have forfeited his vision in sin, he comes to their aid »in new ways « meant to achieve his aim of universal soulmaking of their own autonomous moral volition. If, as has been established in More's critique of Spinozist monism, God is not the extension of mindless matter, his supreme perfection may indeed be that of a supreme lawgiver benignly guiding his creatures towards moral and intellectual perfection: »Why should not God, if he exists and if he is a being distinct from worldly matter, be able to inscribe laws in the minds of men, doing it in such a way, however, that it is up to them whether to obey them or not. Why should he not after their disobedience try in new ways to lead them to good fruits, as he is said to have done on Mount Sinai in giving the Laws to Moses? « ${ }^{58}$ The infinity of the archetypal creative mind's extension is the absolute space of his purposeful agency in all of nature and history.

\subsection{Panpsychism and Divine and Human Agency: The Spirit of Nature}

Divine agency, conceived of as univocal love and goodness along the lines of the author's Christian Platonism, is the key concern of More's anti-Spinozist interpretation of the rationalist notion of the ens perfectissimum. In response to the spectre of Spinozist naturalism, More attributes two kinds of actions to the Deity, one that is mediated by and identical with the life of nature and one that is immediate and supernatural. For one thing, God acts upon the material world through the agency of the spirit of nature by which the intelligible ideas of his supreme intellect gradually shape reality in law-governed organic processes. For another, the spirit of nature, viewed by More as a lesser

57 Confutatio (Op. Omn. II/1, 617).

$5^{8} \quad$ Epistola altera, 43 (Op. omn. II/1, 593). 
metaphysical entity devoid of intellection and volition, is such that God and other spiritual agents may act contrary to its laws whenever they see fit. ${ }^{59}$

More goes to great lengths to rebut Spinoza's devastating critique of purposeful divine agency in general and of miraculous supernatural intervention in particular, as put forward in the Appendix to the first book of the Ethics and the sixth chapter of the Theological-Political Treatise respectively. Spinoza's rejection of divine design and goodness as ill-founded anthropomorphism is shown to flow from the proton pseudos of his metaphysics, namely his naturalism. Once »God « is replaced by »matter«, Spinoza's exposition of divine agency reveals its thinly-veiled naturalist meaning. God's action, conceived of in terms of Cartesian mechanism, is solely that of the motion and rest of mindless material extension: »Nothing is determined by the free will of God [i.e. matter], or his absolute good pleasure, but all things have been determined by the absolute nature of the infinite power of God [i.e. matter]. «60 In response to Spinoza's critique of the classical theism of a divine moral agent, More, for one thing, levels the same objection at the Dutch rationalist in an ad hominem argument. Clearly, geometry, from which Spinoza's notion of God as infinite extension is derived, is as much a product of the human mind as ethics. For another and more importantly, on the logic of the ens perfectissimum theology, it is inadmissible to deny to the divine archetype any of its human image's perfections, let alone its greatest, which is deliberate moral agency:

To do justice to the human mind, since it apprehends excellently all particular things of which it is conscious, the fact that it judges God similar to itself and as a certain eternal and infinite and absolutely perfect omniscient mind, immediately and fully establishes providence. Is this not indeed infinitely preferable to that blind and tumultuous matter? I cannot fail to note how unworthily the fool accuses others here who posit God from their minds, which are free agents or proposing ends to themselves, since he posits matter from his mind, mathematic if your please. ${ }^{61}$

59 The development of More's doctrine of the spirit of nature is traced in detailed analyses of his major writings in Reid 2012: 313-348. Most expositions centre around his controversy with the chemist Robert Boyle, whose experiments More, much to the celebrated scientist's chagrin, sought to interpret as providing empirical confirmation of his metaphysical postulate of a mediating entity. Cf., above all, Henry 1990: 55-76. Again, More's later debate with Spinoza, notably the link between final causality on the one hand and libertarian agency and contingency on the other, adds crucially to our knowledge about a landmark doctrine of Cambridge Platonism.

6o Confutatio (Op. omn. II/1, 622). Translation: Jacob 1991: 78.

61 Ibid. (II/1, 623); translation: ibid., 81. 
Instead, in Spinoza, the attributes of divine extension, notably the necessity by which mathematical proof proceeds, are once again shown to annul the superior ones of divine cogitation. ${ }^{62}$ They, thus, fall of short of God's benign creative and salvific action.

As against the naturalist deity of Spinoza's Treatise and Ethics, More insists upon the Platonic view of God as a supremely good moral agent. Contrary to the infinite power of thought and extension by which Spinoza's substance acts without any purposeful deliberation, let alone moral intention, the omnipotence of More's God is that of his supreme creative and salvific goodness. It is for the sake of the autonomous moral soul-making of rational agents that God calls into being a world, intervening in its affairs either directly or through the agency of his angelic aides whenever he sees fit. More goes to great lengths to establish the distinctness of divine agency from nature. Whereas, for Spinoza, the laws of nature proceed from God and represent his understanding and will which are strictly identical, More views God and nature as two centres of distinct, albeit closely-related, creative agency. In contradistinction to Spinoza's simple substance or nature which both understands and wills the infinity of all possible worlds flowing from its infinite power by necessity, More's creator God is one of univocal goodness. As such, he understands evil when setting out to create a world with which to share his goodness and wisdom in creative power, but he does not will it. He is bound both by conceptual and ethical necessity to act in accordance with his infinite goodness and share with a finite reality the fullness of his own being. However, he is free to choose any single one of the many possible worlds envisaged in the beginning. The identity of divine and natural agency, which More identifies as the speculative core of Spinoza's naturalist critique of miracles, must therefore be rejected on strictly conceptual grounds:

However, this last principle to which the whole proof boils down is utterly false, ... Indeed, God understands the evil order of things, but he does not will it. He understands all the possible varieties of universes that he could create, even though only a single kind exists in actuality. According to this principle, however, all of them would exist as he would will all of them to exist assuming he understood nothing without also willing it, which is an obvious contradiction. ${ }^{63}$

\footnotetext{
62 Cf. ibid.

63 Epistola Altera, 19 (Op. Omn. II/1, 573). More's reductio argument against Spinoza's necessitarian theological actualism is far from conclusive. While man's epistemic access is restricted to one world, this does not rule out that other or indeed all other possible worlds may have existed in the past, exist at present or come to exist in the future.
} 
Of the infinite number of possible worlds, God chooses to create only one, presumably the best of all possible ones, while not actualizing all the others. The world created is not one of dead atoms in motion and at rest in a lifeless void, but instead one animated by what More, as from his Immortality of the Soul of 1659 , calls the »spirit of nature«. Mediating between the supreme intellect and base matter at the top and at the bottom of his Platonic chain of being, the spirit of nature is defined by More as a »substance incorporeal, but without Sense and Animadversion, pervading the whole Matter of the Universe, and exercising a Plastical power therein according to the sundry predispositions and occasions in the parts it works upon, raising such Phaenomena in the World, by directing the parts of the Matter and their Motion, as cannot be resolved into mere mechanical powers. ${ }^{64}$ While devoid of any active intellection and volition itself, it serves God as the natural means to his chief moral end of universal soul-making by preparing matter in such a fashion that it becomes capable of being informed by the creative ideas contained in his perfect archetypal intellect of which the spirit of nature itself is an imperfect mindless image. In More's refutation of Spinoza, it is viewed as the living embodiment of the »universal laws of nature «, which it »embraces ... in a living fashion « ${ }^{65}$ Originally proceeding from God not by the necessity of his essence, but by the benignity of his will alone, it gradually effects the »good of the universe « at large: »The universal laws of nature do not arise from the divine intellect by the same necessity as a property, such as three angles equal to two right angles, from a triangle. Instead, they are inserted into the spirit of nature at the same time it is created by God and, therefore, geared towards the good of the universe «.66 It, thus, executes God's beneficent creative intention of disinterested universal self-communication. As befits its role in God's design, natural causality or the »spirit of nature « as the sum total of its laws is not one of mindless mechanism, but one of living organic growth and flourishing by which it produces and promotes the »good of the universe « at God's behest. As such, the spirit of nature is nothing less than the »the external word of God « by which he bodies forth the intelligible principles and ideas contained in his wisdom: »I reply, however, that I find it quite reasonable that the work and order of nature itself should be called the order, decree or word of God since I view the spirit of nature in which the laws and order of worldly matter are contained, flowing from there into it, as the external word of God.«67 Its laws may therefore be equated with »God's gen-

\footnotetext{
64 Immortality of the Soul III 12,1 (Jacob [1987]: 254).

65 Epistola altera, 18 (Op. Omn. II/1, 573).

66 Ibid., $20(\mathrm{II} / 1,574)$.

67 Ibid. 21, (II/1, 575).
} 
eral providence «: »Therefore, I do not mind admitting at all that God's general providence is contained in the laws and order of this spirit of nature and can thus be rightly called a part of divine providence. ${ }^{68}$

However, while More concurs with Spinoza in viewing nature as God's own mediate providential action, nature or »general providence « needs to be complemented by an immediate »special providence« which he is careful to express in terms of strictly libertarian agency unrestricted by the laws of nature: »However, what I insist upon most emphatically is that there is also God's special providence besides that, one that is administered by himself or through his ministers or angels, as they are generally called, and that it is entirely erroneous to conclude from the fact that the actions of the spirit of nature are called the orders or decrees of God that there are no other divine orders or decrees besides those. ${ }^{69}$ God may choose to ignore the laws contained in the spirit of nature whenever the "good of the universe «, which is the latter's original raison d'être, calls for a demonstration of the enduring benevolence and beneficence of his creative wisdom and power. Aided by his many angels and ministers of grace, he is at liberty to intervene at will so as to reassure humankind of his benign providential care: »Nature has deliberately been created by God in such a way that it obeys its creator and his pleasure as well as the free ministers of his providence in leaving its accustomed order, as they see fit, for the existence of God, the angels and divine providence to be made all the more evident by the fact that not everything depends upon nature alone. «70 Not only, therefore, does the spirit of nature account for the regularity of natural processes by which beings capable of participating in God's fullness gradually come into existence, but also for the contingency of a world open to occasional interventions by supernatural agency, whether divine, angelic or demonic. To the spirit of nature's lesser degree of reality, therefore, corresponds a higher degree of contingency which, in turn, is meant to allow different supernatural agents to exercise different kinds of moral agency, including libertarian choice. In his argument for theological interventionism, More, characteristically, invokes the univocity of divine and human freedom. If man's imperfect libertarian action is not necessitated by natural causality, God's own perfect freedom is clearly all the more exempt from it:

It is the divine intention that, even though they [i.e. the laws of nature] are to work in one and the same mode all the time unless some impediment turns up, their operation, once an impediment is caused by some free agent, is to be

68 Ibid.

69 Ibid.

$70 \quad$ Ibid. $19(\mathrm{II} / 1,573)$. 
suspended or altered. However, God, that uncreated free agent (Agens illud liberum increatum Deum), can with infinitely more ease do what even created free agents (libera Agentia) can do. When there is such a suspension or alteration, which has evidently not been caused by anyone nor by any other visible and perceptible natural cause, the effect may not unreasonably be ascribed to the work of angels or to God himself.

More's a fortiori argument hinges upon the strict libertarianism shared by all the Cambridge Enlightenment thinkers. Not only is freedom a suigeneris causality beyond the laws of nature, but it is tied closely to the categorical imperative of a purgation of all earthly passion and self-will. Besides possessing perfect intellection and volition, God, as a supreme moral agent, must be credited with the highest degree of libertarian freedom unhampered either by the laws of nature or man's inferior motives. While his actions, determined by his goodness, are of necessity benign and beneficent, the course pursued to attain his salvific ends is due to the contingent choice of his wisdom and power alone. Throughout his Ad V.C. Epistola altera, More emphasizes that God may intervene in nature »as the circumstances require it «. ${ }^{71}$ It is meant to bring home the notion of God's moral agency guiding fallen humankind towards its eventual restitution. The interventions of God and his angels in salvation history serve as a soteriological amamnesis by which the fallen souls are reminded of the true intelligible reality which they are called upon to regain in a life of pious virtue and contemplation.

It was shortly after finishing his refutation of Spinoza's Theological-Political Treatise that More came across a treatise by the celebrated physician and fellow Cambridge metaphysician Francis Glisson. Not only did More identify it as another Strato redivivus in Cudworth's categorization of classical and contemporary atheism, but he also chose to wield his anti-Spinozist argumentative weaponry to combat materialist panpsychism in general.

\section{Panentheist Panpsychism, Panpsychist Panentheism-More's Critique of Glisson's Energetic Nature}

Shortly after the publication of the Treatise on Energetic Nature by biologist and physician turned metaphysician Francis Glisson in 1672, More subjected the titular concept to detailed philosophical critique, rejecting it as yet another form of hylozoism in the Spinozist vein. A major part of the »scholia« or comments

71 It is not a figure of speech, but a leitmotif recurring throughout More's first anti-Spinozist treatise Cf., e.g., ibid. 11 (II,1, 570), 19 (II/1, 573), 21 (II/1, 575). 
appended to his original refutation of Spinoza's Theological-Political Treatise in the Ad V.C. Epistola altera consists in a sustained refutation of Spinoza's kindred spirit. ${ }^{72}$

In his refutation, More is quick to identify Glisson as a Spinozist. Just as the »impure sophist « views material substance as necessarily existent by itself, so does the celebrated physician view matter per se as being endowed with perception, striving and self-motion: »Like Spinoza who holds that all substance, insofar as it is substance, exists from itself because it subsists through itself, he contends in that work that substance, insofar as it is substance, is necessarily alive by the force of its nature, i.e., it perceives, strives and moves itself. He therefore assumes that the perceptive, appetitive and motive faculties are all intrinsic parts of matter itself.« ${ }^{73}$ Moreover, aligning Spinoza and Glisson in their commitment to necessary existence and necessary animation respectively, More identifies the vitalism shared by his two opponents as a variety of constitutive panpsychism that is meant to render the belief in a creator distinct from the one living substance of nature superfluous to account for the emergence of life: »And certainly, bolstered by the Spinozist view of the necessary existence of every substance as substance, the Glissonian way is such that it clearly supposes that there is no need of a creator God at all. « ${ }^{74}$ Several of the arguments against Glisson's panpsychism advanced in the scholia may well be seen as »an exercise in question-begging of astonishing impudence.$^{75}$ Time and again, the English Platonist simply restates his cherished doctrine of the spirit of nature without offering any further philosophically substantial argument, simply placing the onus probandi upon his hylozoist opponent. Thus, he disagrees with Glisson's hylozoist conclusions regarding Bacon's typology of motions which, in contrast, he chooses to view as originating in a spiritual principle distinct from matter. Likewise, More shares Glisson's admiration for the beautifully-wrought structures of apparently inanimate phenomena like "snow, rime, hail and the like in a microscope «, quoting with approval the Cambridge physician and metaphysician's praise of their »exceeding elegance

72 Deeply steeped both in Francisco Suarez's late medieval metaphysics and Francis Bacon's early modern science, the Cambridge physician and philosopher's Glisson's concept of energetic substance has only very recently been recognized as a deeply original panpsychist metaphysics. There is a fine thesis devoted to Francis Glisson: Hartbecke 2006, which examines the author's thought in relation to his scholastic role model Suarez. A brief analysis of More's refutation of Glisson's principal work is provided in Henry 1987: 15-40.

73 Scholia in Epist. ad V.C. (Op. Omn. II/1, 604).

74 Ibid. (II/1, 605).

75 Henry 1987: 32 . 
and well-nigh inimitable art « ${ }^{76}$ However, while Glisson takes nature's artful design to be evidence of the life of energetic matter, More instead attributes it to the purposeful, albeit unconscious, work of the spirit of nature which pervades the whole of nature as a mediating principle inferior to God, but superior to matter: »For I, too, acknowledge gladly that the shapes of so-called inanimate bodies are the effects not of mechanism, but the spirit of nature. And it is manifest that these phenomena do not by any means indicate a life of matter proceeding or unfolding from it, but only the life of the universe or the spirit of nature actuating the whole of worldly matter. ${ }^{77}$ Finally, while More is right in pointing out that a projectile sustaining its motion hardly bears out a perceptive and appetitive power in lead, his own recourse to rising quicksilver in a thermometer is equally unlikely to be considered a compelling argument for the existence of his own »hylarchic principle« or »the hylostatic power of the spirit of the universe ${ }^{78}$ i.e. the spirit of nature.

Still, although many of his arguments against Glisson may be said to fall flat, More's refutation is remarkable on two grounds. For one thing, More himself, for all his misgivings about panpsychism, comes close to restating his early panpsychist doctrine of his correspondence with Descartes and endorsing a variety of »hylozoism « on theological grounds. All of reality, proceeding as it does from the Deity's supreme life, is seen as the latter's »ultimate emanation « and as such may possess some rudimentary living »self-motion « after all: »Hence, it is manifest that there may be a life without perception or appetite

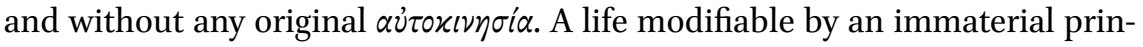
ciple in various ways is the one and only life that I am prepared to admit as being deeply rooted in matter. In fact, I am all the more willing to concede that lest the ultimate emanation from the first source of life seem entirely devoid of life ${ }^{79}{ }^{79}$ For another, More holds that panpsychism, while being consonant with, and perhaps even implied by, the soul's innate notion of a benign deity as all-diffusive life, cannot by itself account for the unity characteristic of the animate cosmos as an ordered whole and its living parts. The emergence of advanced animal and human life, let alone that of the living order of creation, is bound to remain as mysterious on the principles of Glisson's panpsychism as it is on those of Hobbesian or Cartesian mechanism:

Indeed, if there were a kind of primordial life of matter, it would only be generic. As regards its specific modifications, it would be spread and disseminated across

\footnotetext{
${ }_{76}$ Scholia in Epist. ad V.C. (Op. Omn. II/1, 6o6).

77 Ibid.

78 Ibid

79 Ibid. (II/1, 6o8).
} 
vast distances. It is no more helpful to assume such a kind life to account for the order and beauty of the world than none at all. If there is not something preconceiving and foreseeing the whole fabric of the world and the mutual relationships between its single parts at once, its creation will indeed occur as blindly and fortuitously as if it were created by mere mechanical motion. Of so little worth is the notion of that primordial life that is to split up into various physical forms afterwards. ${ }^{80}$

More's counterargument hinges upon the combination problem which deprives panpsychism of its alleged explanatory power. The complexity of an animal organism militates strongly against the truth of modern Glissonian panpsychism. It is inherently unlikely that the single parts of the generic life of matter, »spread and disseminated across vast distances«, should consciously and purposely collude in producing the »specific modifications« required for a well-functioning living organism. Among the examples adduced are the aquatic bird whose wings have come to be such that it can easily cast off the water on re-emerging from the sea or that of a cock capable of taking part in a fight, which More describes with obvious gusto. Perhaps drawing upon his own eye-witness experience, he ridicules the conclusion inevitable on panpyschist principles that each single body part of a cock, quite implausibly, must have been aware of the finer details of a cock fight from its birth: $\mathrm{Oh}$, what express ideas and imaginings must they hence possess, notably of their bladelike spurs with which to gouge out or tear apart their rivals' brains in a consciously-dealt out blow! « ${ }^{81}$ Moreover, even if such knowledge were to be granted to the single body parts, an emergence of complex organisms from simple atom lives would call for a degree of cooperation on their part that is clearly at odds with the egotism inherent to Glisson's Spinozist concept of each body's self-centred conatus. Assuming that all natural atoms were to possess the same knowledge about the future organism, whether it is an aquatic bird or a cock, they would be most unlikely to subordinate their own interests to the greater good of the one living whole. Instead, More imagines the atom lives to engage in a fierce struggle as they vie with one another for the privilege of constituting the higher faculties of the future organic whole of which they are supposed to be parts:

After all, all parts of earthly matter and the matter surrounding it are believed to be intent solely upon their own concrescence and substance. Thus, if these substances chance to act upon one another in their concrescence, they seek to realize their own form only. Yet, none of them is animate so that it would be either impossible or completely fortuitous if any living form were to emerge from

$80 \quad$ Ibid. (II/1, 6o8-6o9).

81 Ibid. (II/1, 6og). 
that. However, living forms are the greatest mark of wisdom and providence that we find in the universe. ${ }^{82}$

The aporia of the combination problem is further exacerbated by the existence of self-conscious subjectivity. If the chaotic multiplicity of conscious or proto-conscious matter cannot account for the organic unity of animal life, Glisson's Spinozist panpsychism is even less qualified to render intelligible the existence of the supreme oneness of a self-conscious human mind. Again, the many simple perceptions attributed to the atoms of living matter fail to add up to the unity of a human mind's complex perception, nor does Glisson's postulate of the energetic nature's "perception of perception « remedy the aporia of a strong emergentism marring his panpsychism altogether. »Duplicate perception «, by which energetic matter is supposed to appropriate the many »simple perceptions « of all living forms and shapes allegedly caused und sustained by it, fails on numerous grounds. For one thing, perception, by its very nature, is simple. There is no such thing as a visual perception of the human eye which is consecutively perceived by the common sensorium and the intellect so as to yield a unified sense impression. Instead, perception, while involving the soul's "plastic power by which it interacts with the spirit of nature shaping its bodily sense organs, is grounded in the strict unity and simplicity of the consciousness of sense perception which is the sine qua non of the epistemic process in question: »By the same act by which a sentient being perceives an object, it also perceives that it perceives the object. And this does not require a new act unless perhaps someone should raise a doubt whether it perceives «.83 The single act of perception, hence, is not that of matter particles mutually perceiving each other's perceptions which then somehow add up to acts of complex sensation. Instead, it is identical with a single soul's consciousness of its sense impressions which is prior and superior to the inferior plasticity of its sense organs. For another, the postulate of atom lives endowed with perception cannot but lead into the aporia of the emergent subject's necessary awareness of, if not detailed knowledge about, all the many distinct centres of consciousness of which its own subjectivity is supposedly made up. In other words, as More is careful to point out in an ad hominem argument against the physician Glisson, if the hylozoism of the Spinozist variety were true, the subject or, in Glissonian parlance, the complex »suppositality« or »modal subsistence« that is the conscious rational self, would have to possess an anatomic expertise on a par with that of the author of the Treatise on the Energetic Nature of Substance himself:

$82 \quad$ Ibid.

83 Ibid. (II / 1,610$)$. 
If the single natural atoms of matter which are joined together or coalesce into my >suppositality< or my >modal subsistence whole fabric of my body and its organisation in which their plastic power consists and if, as is held by that famous Glisson, the plastic power or natural life persists in the animals formed, overseeing their natural constitution and governing it by means of its perception, appetite and motion, then it seems clearly impossible that I who am this >suppositality< or >supposite < should not understand the plastic perception of this supposite, i.e., of myself, and should not have the most accurate anatomical understanding of my body. ${ }^{84}$

This absurd inference is avoided on the principles of More's own refined Platonist variety of panpsychism which denies consciousness to the soul's lower powers, notably its plastic ones of organic self-formation. Since perception originates in the soul's higher substance, its ignorance about the minutiae of its physical functions does not pose a problem to Morean panpsychism with its complimentary axioms of the creative ens perfectissimum and the topdown-causality exercised by it. The first cause must not be conceived as a distracted multitude, but as a supremely unitary intellect contemplating in itself the structured whole of the universe. Hence, if it were not for a consummate mind, a creation of spiritual substance conceived as a myriad of unconnected centres of consciousness would be every bit as random as a creation from material substance:

How, for example, should matter which is the least unitary of all substances, consisting of countless physical monads and natural atoms only, fulfil those tasks which require unity in the most absolute sense imaginable? For such must be that substance which foresaw and understood the most beautiful order and the mutual relationships of all the ideas of all these things at once, always contemplating in itself the ideas of all things with one single stabile and immutable glance. It is a kind of eternal perfect mind which preconceives in itself the ideas of all future created things and which pours them forth into its vicarious power, the spirit of nature, and all over matter in a vital, not in an intellectual fashion. ${ }^{85}$

Returning to his original position outlined in his early correspondence with Descartes, More, in response to Spinoza's and Glisson's »hylozoism«, subscribes to a panpsychist ontology himself. However, it is supplemented by the boniform vision of God's universal goodness and perfect mind which continuously guides the many centres of consciousness and agency towards the participation in the fullness of his own »perfect life «.

$84 \quad$ Ibid.

85 Ibid. (II/1, 6o8-6og). 


\section{God or Living Space-The Relevance of Morean Trialism of Extended Substance}

More provides a first major response to the most influential early modern systems of panentheism and panpsychism. His own metaphysics which is meant to remedy the shortcomings of Cartesian mechanism and Spinozist hylozoism emerges as an original system of early modern rationalism in its own right.

On More's principle of panentheism of space and panpsychism of life and nature, there are three closely-linked, yet distinct, strata of being each of which is endowed with its own kind of autonomous agency. At the apex of More's hierarchy of animate being is God who is defined as an infinitely-extended consummate mind of absolute creative goodness. Throughout, the unshakeable foundation of More's Platonism is God's universal and disinterested goodness intuited by the soul as an indubitable first truth in immediate vision. It calls for an ontology that does justice both to God's transcendence to and immanence in all things. God, for one thing, must be transcendent since he cannot be the author of evil, whether natural or moral. Instead, God endows all of material reality with a spiritual agency of its own by which it may gradually come to participate in his universal self-communication. Of the possible finite worlds which God is at liberty to create, he chooses the one which allows all of reality to participate in him. The best possible world, in other words, is a panpsychist one in which all creatures have the capacity for participation in the fullness of the divine life. For another, God must be omnipresent as the formal and final cause of all reality. His infinite extension is such that it, quite literally, contains in itself all finite extensions upon which God acts both through the laws of nature embodied by the universal spirit of nature and in occasional miraculous intervention.

More's metaphysical system is clearly not without weaknesses. Surprisingly, he fails to address the relationship between space and the spirit of nature which should be seen as co-extensive spiritual extensions. As well as being important for reasons of the general coherence of his metaphysical system, it is crucial to More's theory of divine agency, as it is difficult to see how space may act upon or »touch « the finite agents and atoms that inhabit its infinitely many places. It is particularly problematic considering More's strict interventionism which poses formidable problems of its own in terms of theodicy. Throughout, More himself seems to vacillate between an identification of God and space and an interpretation of the latter as a mode of the former's omnipresence. On the principles of his Christian Platonism, spatial infinity, suffused by the principle of organic life, should best be seen as a symbol and image of the ens perfectissimum's supreme creative goodness whose vision is the first cause 
and final purpose of all natural and moral agency, calling upon all creatures to share its riches.

More's doctrine of God as the infinite space of the divine life in nature provides both a powerful response to Spinoza's Deus sive natura and a remarkable system of early modern panentheism and panpsychism.

\section{References}

Anfray, J.P. (2014) »Partes extra partes. Étendue et impénétrabilité dans la correspondance entre Descartes et More.«Les Études Philosopiques 1, 37-59.

Assmann, J. (2007) Moses der Ägypter. Entzifferung einer Gedächtnisspur, Frankfurt.

Becco, A. (1978) »La substance unique face aux substances simples. D'H. Morus à G.W. Leibniz.« In: Marco M. Olivetti (ed.) Lo Spinozismo Ieri e Oggi. Padua: Cedam, 103-119.

Boylan, M. (1980) »Henry More's Space and the Spirit of Nature«, in: Journal of the History of Philosophy 18, 395-405.

Breteau, J.L. (2006) » Le fantôme de Straton s'est récemment remis à marcher: les platoniciens de Cambridge et l'hylozoïsme«, Kairos 28, 45-72.

Cassirer, E. (2002) »Die Platonische Renaissance in England und die Schule von Cambridge» (1932) In: E. Cassirer, Gesammelte Werke, 14. Darmstadt: Wissenschaftliche Buchgesellschaft, 223-380.

Colie, R. (1957) Light and Enlightenment. A Study of the Cambridge Platonists and the Dutch Arminians, Cambridge: CUP, 66-93.

Colie, R. (1964) »Spinoza in England, 1665-1730.« Proceedings of the American Philosophical Society 107, 183-219.

Cudworth, R (1678) The True Intellectual System of the Universe, London: Printed for Richard Royston, 1678 .

Darwall, S. (1995) The British Moralists and the Internal>Ought: 1640-1740. Cambridge: CUP, 109-148.

Gabbey, A. (1903) »Responsio ad Fragmentum Cartesii. Avertissement.« In: Charles Adam/Paul Tannery (eds.) CEuvres de Descartes V: Correspondance. Mai 1647-Février 165o. Paris (Reprint Paris: Vrin. 1996), 628-642.

Gabbey, A. (1982) »Philosophia Cartesiana Triumphata: Henry More (1646-1671).« In: Thomas M. Lennon/John M. Nicholas/John W. Davis (eds.) Problems of Cartesianism. Kingston/Montreal: McGill-Queen's University Press, 171-249.

Gill, M.B. (2006) The British Moralists on Human Nature and the Birth of Secular Ethics. Cambridge: CUP.

Hartbecke, M. (2006) Metaphysik und Naturphilosophie im 17. Jahrhundert. Francis Glissons Substanztheorie in ihrem ideengeschichtlichen Kontext. Tübingen: Max Niemeyer Verlag. 
Hedley, D. (2000) Coleridge, Philosophy and Religion. Aids to Reflection and the Mirror of the Spirit, Cambridge: CUP.

Hedley, D. (2017) »Gods and Giants: Cudworth's Platonic Metaphysics and his Ancient Theology. « British Journal for the History of Philosophy 25, 932-953.

Hengstermann, C. (2017) »Pre-existence and Universal Salvation-The Origenian Renaissance in Early Modern Cambridge.« British Journal for the History of Philosophy 25, 971-989.

Hengstermann, C. (in print b) »Cogitatione attingere. Divine Sensation in René Descartes and the Cambridge Platonists.« In: id. (ed.) The History of the Religious Imagination in Christian Platonism: Exploring the Philosophy of Douglas Hedley. London et al.: Bloomsbury.

Hengstermann, C. (in print a) »The Cambridge Platonists«, in: Steward Goertz/Charles Taliaferro (eds.) The Wiley-Blackwell Encyclopedia of Philosophy of Religion (in print) Henry, J. (1987) »Medicine and Pneumatology. Henry More, Richard Baxter, and Francis Glisson's Treatise on the Energetic Nature of Substance. « Medical History 31, 15-40.

Henry, J. (1990) »Henry More verses Robert Boyle. The Spirit of Nature and Nature of Providence.« In: Sarah Hutton (ed.) Henry More (1614-1687). Tercentenary Studies. Dordrecht et al.: Kluwer, 55-76.

Hutton, S. (1984) »Reason and Revelation in the Cambridge Platonists, and their Reception of Spinoza.« In: Karlfried Gründer/Wilhelm Schmidt-Biggemann (eds.) Spinoza in der Frühzeit seiner religiösen Wirkung. Heidelberg: Verlag Lambert Schneider, 181-200.

Hutton, S. (2015) British Philosophy in the Seventeenth Century. Oxford: OUP.

Jacob, A. (1991) Henry More's Refutation of Spinoza, Hildesheim/Zurich/New York: Olms, 1991.

Jacob, A. (1995) Henry More's Manual of Metaphysics. A Translation of the Enchiridium Metaphysicum. (1679) With an Introduction and Notes, 2 vols., Hildesheim/Zurich/ New York: Olms.

Koyré, A. (2008) From the Closed World to the Infinite Universe, Reprint Radford: A \& D Publishing.

Leech, D. (forthcoming) »An Early Critique of Spinoza: More's Confutatio (1679)«

Leech, D. (2014) »More et la lecture athée de Descartes.«Les Études Philosopiques 1, 81-97.

Leech, D. (2013) The Hammer of the Cartesians. Henry More's Philosophy of Spirit and the Origins of Modern Atheism, Leuven/Paris/Walpole, MA: Peeters.

Lovejoy, A.O. (1908) »Kant and the English Platonists«, in: R.S. Woodworth (ed.) Essays Philosophical and Psychological in Honour of William James, London: Longmans, Green, 1908, 265-302.

More, H. (1651), Second Lash of Alazonomastix, Cambridge: Printers to the University of Cambridge, 1651 . 
More, H. (1679), Opera omnia, 3 vols., London: J. Maycock, for J. Martyn and W. Kettilby: 1675-1679 (Reprint Hildesheim: Olms, 1966).

More, H. (1987) The Immortality of the Soul. edited by Alexander Jacob. Dordrecht/ Boston/Lancaster: Martinus Nijhoff Publishers.

Pacchi, A (1973) Cartesio in Inghilterra. Da More a Boyle, Rome: Editori Laterza.

Reid, J. (2012) The Metaphysics of Henry More, Dordrecht et al.

Reid, J. (2013) »Henry More and Nicolas Malebranche's Critiques of Spinoza.« European Journal of Philosophy 23, 764-792.

Rupert Hall, A. (1990) Henry More and the Scientific Revolution. Cambridge: CUP, 1990.

Schneewind, J.B. (1998) The Invention of Autonomy. A History of Modern Moral Philosophy. Cambridge: CUP.

Schütt, H.P. (1981) »Zu Henry Mores Widerlegung des Spinozismus.« In: Konrad Cramer et al. (eds.) Spinozas Ethik und ihre frühe Wirkung, Wolfenbüttel: Herzog August Bibliothek, 19-50.

Skrbina, D. (2017) Panpsychism in the West. Revised Edition, Cambridge, MA/London: The MIT Press, 2017.

Taliaferro, C. (2005) Evidence and Faith. Philosophy and Religion since the Seventeenth Century. Cambridge: CUP.

Thiel, U. (1991) »Cudworth and Seventeenth-Century Theories of Consciousness.« In: Stephen Gaukroger (ed.) The Uses of Antiquity. The Scientific Revolution and the Classical Tradition. Dordrecht/Boston: Springer, 79-99.

Thiel, U. (2011) The Early Modern Subject. Self-Consciousness and Personal Identity from Descartes to Hume. Oxford: OUP. 